\title{
Not Being Content with God: Contestation and Contradiction in Communities under Duress
}

\author{
L. Juliana ClaAsSens (STEllenbosch University)
}

\begin{abstract}
Drawing on recent insights from trauma hermeneutics, this article sets out to investigate the sharply divergent divine metaphors used by Jeremiah while being in prison (Jer 20). In this text, one finds Jeremiah saying in so many words that he hates God; that God had violated him (Jer 20:7). However, in the same breath, he also confesses God to be the Liberator-Warrior God who delivers the needy from the hands of evildoers (Jer 20:11, 13). These divine metaphors that are rooted in contestation and contradiction reflect the deep-seated paradox of faith experienced by the prophet that quite likely also manifested in the people during the time of the Babylonian invasion and exile. In addition, this article explores the dramatic (re)descriptions of God in Jer 20 that supplement and challenge the more traditional ways of speaking about God with equally contentious and contradictory images for God that emerged in communities experiencing severe trauma such as during the Holocaust as well as the forced removals during the Apartheid era in South Africa. I propose that new images for God that are marked by contradiction serve as a vital means to challenge traditional, often simplistic understandings of God in the name of God that is essential if God is going to survive together with the people.
\end{abstract}

KEYWORDS: Jeremiah; Trauma Hermeneutics; God-language; Holocaust; Apartheid

\section{A "IN GOD'S NAME, GOD!"}

Some time ago, one of my favourite Dutch artists, Herman van Veen, came to visit my hometown, Stellenbosch, South Africa. In the beautiful Oude Libertas amphitheatre one summer evening in January, Van Veen performed a striking song in which he offered the following challenge to God: ${ }^{1}$

* Submitted: 4/05/2017; peer-reviewed: 17/08/2017; accepted: 24/08/2017. L. Juliana Claassens, "Not Being Content with God: Contestation and Contradiction in Communities under Duress," OTE 30 no. 3 (2017): 609-629. DOI: https://doi. org/10.17159/2312-3621/2017/v30n3a5

1 The original Dutch lyrics are as follow:

"Waar is die god, die zegt dat mijn zoon

Niet anders dan vrouwen beminnen mag, meneer? 
Where lives the god that says that my daughter only should love a man?

Where hides the god that claims that children are the property of adults?

Where speaks the god that maintains that one who has so much more than others is no thief?

In the dramatic conclusion of the song, Van Veen asks: "Where lives the god ...Where hides the god ...Where speaks the god? Where in god's name, god?"'

This compelling song clearly stems from the great pain that God's representatives on earth have caused in the name of God to real flesh and blood people: To the LGBTIQ community, and quite dramatically also in my own church community, ${ }^{3}$ by prescribing who they can and cannot love. Also, the children involved in the child abuse scandals in the Catholic Church where church leaders, representatives of the divine, violated the bodies and psyches of so many young children around the world, not only damaged them but also erased the trust of the community in the church. To the victims of a Wealth-Health-Prosperity theology that maintains that material blessings are the just reward of the faithful, hence encouraging the great divide between rich and poor to grow even more pronounced. One can add to Van Veen's litany the numerous instances of

Waar huist die god, die zegt dat mijn dochter

Niet anders dan mannen beminnen mag, meneer?

Waar schuilt die god, die van mening is

Dat kinderen eigendom van volwassenen zijn, meneer?

Waar leeft die god

Die voelt dat liefde selectief is, meneer?

Waar spreekt die god

Die meent dat hij of zij, die zo veel meer en meer nog dan anderen heeft, geen dief is Meneer?"

2 The original Dutch lyrics are as follow:

"Waar is die god?

Waar huist die god?

Waar schuilt die god?

Waar leeft die god?

Waar voelt die god?

Waar spreekt die god?

Waar in godsnaam god?

(meneer)"

3 Pieter Steyn, "NG Kerk besluit wéér teen gays," Netwerk24 (10 November 2016), online: http://www.netwerk24.com/Nuus/Algemeen/ng-kerk-besluit-weer-teen-gays20161110. 
violence conducted in God's name, as well as the justification of Apartheid, slavery and gender inequality that have been, and in some instances still are, attributed to God. ${ }^{4}$

It is evident in Van Veen's song that he is not content with God, or at least the construction of God upheld in many religious communities today. What is interesting, though, is that Van Veen presents his challenge of God in the name of God. "In god's name, god!" ("In godsnaam god!"). This inclination to challenge portrayals of God that are limiting and even harmful to people today is reminiscent of John Caputo's assertion that it is "in the best interest of theology not to be content with God." Caputo shows the importance of challenging what he calls "weak theology that gives words to God, to what is going on in the name (of) God." "This challenge, ironically, is presented in terms of what Caputo calls, the "weakness of God" - something that he describes as the "unconditional, undeconstructable tenants of a type of proto-religion rooted in faith, hope, love and justice." 7

In the spirit of challenging God in the name of God, I propose that it is in communities under duress that new language for God emerges. Drawing on recent insights from trauma hermeneutics, the first part of this article seeks to investigate the sharply divergent divine metaphors used by Jeremiah while being in prison (Jer 20). In this text, Jeremiah says in so many words that he hates God; that God had violated him (Jer 20:7). However, in the same breath, he also confesses God to be the Liberator-Warrior God who delivers the needy from the hands of evildoers (Jer 20:11, 13). These divine metaphors that are rooted in contestation and contradiction reflect the deep-seated paradox of faith experienced by the prophet that, quite likely, also belonged to the people during the time of the Babylonian invasion and exile.

The second part of this article explores the dramatic (re)descriptions of God in Jer 20 that supplement and challenge the more traditional ways of speaking about God with equally contentious and contradictory images for God that emerged in communities under severe trauma such as the Holocaust as well as

4 Eric Seibert, The Violence of Scripture: Overcoming the Old Testament's Troubling Legacy (Minneapolis, MN: Fortress, 2012), 15-23.

5 The title of this article is derived from Caputo's recent book. See John Caputo, The Folly of God: A Theology of the Unconditional (Eugene, OR: Polebridge Press, 2016), 1.

6 Caputo, Folly of God, 53. Cf. also Kathleen O'Connor's description of the way in which the book of Lamentations speaks about God that "smashes images of a God harnessed to our bidding. It disrupts theologies of a God who makes us prosper in all things, rescues us from every evil, and longs always to be with us." See Kathleen O'Connor, Lamentations and Tears of the World (Maryknoll, NY: Orbis Books, 2002), 110.

7 Caputo, Folly of God, 35. 
the forced removals during the Apartheid era in South Africa. I propose that new images for God that are marked by contradiction serve as a vital means of challenging traditional, often simplistic understandings of God in the name of God that is essential if God is going to survive together with the people. ${ }^{8}$ Before I address Jer 20, I present a brief discussion of the importance of the relatively new approach of trauma hermeneutics in order to illuminate my exploration of God-language emerging from communities under duress.

\section{B TRAUMA HERMENEUTICS AS INTERPRETATIVE LENS}

In recent years, trauma hermeneutics has become an increasingly important conversation partner in the study of the HB. Using insights gleaned from trauma theory in order to make sense of the literature arising from the incredibly tumultuous time in Judah's history associated with military invasion and deportation by the hand of the Babylonian Empire, especially the biblical prophets, and in particular the book of Jeremiah, has offered fertile ground for applying trauma hermeneutics as an interpretative lens. ${ }^{9}$

In this regard, Kathleen O'Connor ${ }^{10}$ and Louis Stulman ${ }^{11}$ have been pioneers in demonstrating how trauma hermeneutics may help us to better understand the community's often confounded struggle to make sense of devastating

8 Kathleen O'Connor writes that "they may survive as a people, but only if God survives the nation's destruction." See Kathleen O'Connor, "A Family Comes Undone," RevExp 105/2 (2008): 209. Cf. also Andrea Fröchtling, Exiled God and Exiled Peoples: Passionis and the Perception of God during and after Apartheid and Shoah (ÖSt 22; Berlin: LIT Verlag, 2002), 120-121.

9 Garber's article offers a helpful discussion of the development as well as the impact of trauma hermeneutics on biblical studies. See David G. Garber, "Trauma and Biblical Studies," CurBR 14/1 (2015): 24-44. Cf. also two collections of essays that contain some of the most important voices in trauma hermeneutics and biblical studies. Elizabeth Boase and Christopher G. Frechette, eds., Bible through the Lens of Trauma, SemeiaSt 86 (Atlanta, GA: Society of Biblical Literature Press, 2016) and Eve-Marie Becker, Jan Dochhorn, and Else Holt, eds., Trauma and Traumatization in Individual and Collective Dimensions: Insights from Biblical Studies and Beyond (Göttingen: Vandenhoeck \& Ruprecht, 2014).

10 Kathleen M. O'Connor, "How Trauma Studies can Contribute to Old Testament Studies," in Trauma and Traumatization in Individual and Collective Dimensions: Insights from Biblical Studies and Beyond, ed. Eve-Marie Becker, Jan Dochhorn, and Else Holt (Göttingen: Vandenhoeck \& Ruprecht, 2014), 213. Cf. also Kathleen M. O'Connor, Jeremiah: Pain and Promise (Minneapolis, MN: Fortress, 2011).

11 Louis Stulman, "Reading the Bible through the Lens of Trauma and Art," in Trauma and Traumatization in Individual and Collective Dimensions: Insights from Biblical Studies and Beyond, ed. Eve-Marie Becker, Jan Dochhorn, and Else Holt (Göttingen: Vandenhoeck \& Ruprecht, 2014), 189. Cf. also Stulman's commentary on Jeremiah: Louis Stulman, Jeremiah, AOTC (Nashville, TN: Abingdon, 2005) and his monograph 
events, such as when the mighty armies of Nebuchadnezzar swept across the Judean countryside from 597-587 BCE, destroying everything in its way including the city of Jerusalem and its temple. Kathleen O'Connor describes the goal of trauma and disaster studies as seeking to comprehend "the life-destroying effects of violence upon people and ultimately to find processes that help people to endure, survive, and perhaps eventually [even to] thrive." 12

Viewed in terms of trauma hermeneutics, the book of Jeremiah, in the first instance, constitutes an important step in helping people to face trauma. According to O'Connor, trauma leaves its victims numb, without language. Stuck in a "kind of half-life," trauma victims typically find themselves "unable to move toward recovery or to flourish as vital human beings." 13 The images, metaphors, and stories found in Jeremiah thus serve as a valiant attempt to break through the silence; the prophet helping his people to put into words that which had been thus far beyond description. ${ }^{14}$

However, equally important is also the book of Jeremiah's many attempts to address the existential and theological crisis that the people of Judah experienced when faced by the violent destruction of their city and temple. As O'Connor writes: "After all, God did not protect them, nor did prayer comfort them, nor is worship any longer possible because the gods of chaos rule the cosmos." 15 Indeed, as she argues elsewhere, it is not surprising that, "in disasters, faith collapses along with everything else." 16

It is this position that offers also a point of connection with future communities under duress. As I argue in this article, in Jer 20 as well as in communities from a very different time and place, traumatic events are responsible for believers starting to challenge their previously held conceptions of God. In this regard, trauma hermeneutics is a helpful methodological approach as it assists us in appreciating the ways in which, as part of the process of making sense of the senseless, believers may invent alternative ways of speaking about what trauma they had experienced, thus moving through the pain and eventually beyond it. ${ }^{17}$ With a special focus on Jer 20, I propose that in finding new language to speak

on the prophetic literature read through the lens of trauma hermeneutics in conjunction with Kim: Louis Stulman and Hyun Chul Paul Kim, You are My People: An Introduction (Nashville, TN: Abingdon, 2010).

12 O'Connor, Jeremiah, 2.

13 O'Connor, Jeremiah, 2.

14 O'Connor writes how these metaphors evoke "associations, feelings, and ideas that lure us into the imagery and show us what we had not seen before." See O'Connor, Jeremiah, 35.

15 O'Connor, Jeremiah, 4.

16 O'Connor, Jeremiah, 25.

17 O'Connor, Jeremiah, 57. 
to and about God is an important element of responding to trauma that also constitutes a crucial step along the often difficult road towards healing and recovery.

\section{SPEAKING FROM PRISON}

In Jer 20, the threat to Jeremiah's life has escalated to the extent that he finds himself in prison with the High Priest Pashhur, himself being responsible for incarcerating the prophet in the temple and subjecting him to great physical violence and mental anguish.

Jeremiah's experience of being in prison, along with the physical and emotional harm that he experienced, mirrors the plight of the people facing impending violence and doom that threatened all of Judah. ${ }^{18}$ The prophet, in response to his experience of violence and abuse, renames the High Priest Pashhur in terms of the infamous designation, "Terror-is-all around" (NRSV Jer 20:3), which throughout the book of Jeremiah is used to illustrate the utter devastation of the nightmare in which the people of Judah found themselves (Jer $6: 25 ; 20: 10 ; 46: 5)$. Pashhur's new name thus points beyond the suffering he inflicted on Jeremiah to violent death by the sword and plundering the city's wealth by the Babylonian invaders, in addition to the forceful removal of the city's inhabitants (Jer 20:4-6) that was to come. ${ }^{19}$

The depths of Jeremiah's suffering in prison are twofold. On the one hand, the prophet is particularly hurt by the betrayal by his own family and friends who are justifiably disturbed by his message of violence and destruction (Jer 9:4-5; 12:6). Jeremiah laments that he has become, "a laughingstock all day long; everyone mocks" him (NRSV Jer 20:7). In response to his message, "Terror is all around," he hears people whispering: "Denounce him! Let us denounce him!" (NRSV Jer 20:10). His closest friends are the ones who are waiting for him to stumble, saying: "Perhaps he can be enticed, and we can prevail against him, and take our revenge on him" (NRSV Jer 20:10). ${ }^{20}$

18 In his personal life, Jeremiah personifies or embodies the social disintegration experienced by the people of Judah during the Babylonian invasion, O'Connor, Jeremiah, 71-73; Cf. also her article, Kathleen O'Connor, "Surviving Disaster in the Book of Jeremiah," WW 22/4 (2002): 377.

19 Ironic, then, is that Judah's religious leaders, and also Pashhur who is now causing so much anguish in the life of Jeremiah, will themselves be subjected to violence and incarceration. They will be taken into captivity to Babylon for what essentially will be a life sentence (Jer 20:6). Cf. Jack Lundbom, Jeremiah among the Prophets (Eugene, OR: Cascade Books, 2012), 53.

20 Cf. also the threat to Jeremiah's life in Jer 11:19 and 18:23 that exemplifies his experience of being violated, O'Connor, Jeremiah, 84; O'Connor, "Surviving Disaster," 376. 
Perhaps even a greater source of anguish than the experience of rejection and treachery from those closest to him is the serious crisis in faith the prophet experienced due to the situation of extreme trauma in which he finds himself. In Jer 20:7, Jeremiah lashes out against God, saying that God has "enticed" or

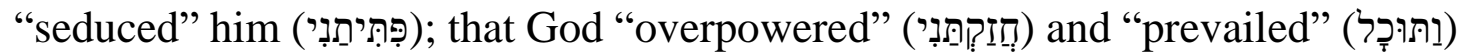
against him (own translation). According to Louis Stulman, the language of "overpowering" signifies an act of "seizing, compelling, strengthening, taking hold of, and even raping (Deut 22:25)." 21 Stulman's interpretation of "overpowering" in terms of sexual violence concurs with that of Susanne Scholz who, in no uncertain terms, maintains that in this poem, "God appears to rape the male prophet." 22 According to Scholz, this line of interpretation can be traced to Abraham Heschel who first raised the possibility of rape in terms of the combined verbs "persuade" and "overpower." 23 Also, Angela Bauer, in her monograph on Gender in Jeremiah, argues that the piel form of the verb ("seduce"/ "persuade") used together with the hiphil form of the verb ("overpower") clearly has sexual connotations, which according to her invite a reading of Jer 20:7 that speaks of the "prophet's experience of sexualized violence at the hands of the deity." 24

Kathleen O'Connor elaborates on the proposal that the language of sexual violation throughout the book of Jeremiah is used to describe the physical and also emotional violation experienced by the prophet and his people. ${ }^{25}$ Elsewhere in Jeremiah, gender-based violence is used to describe the anguish and trauma associated with the build-up and aftermath of the Babylonian invasion and captivity. ${ }^{26}$ For instance, in Jer 13:22, the metaphor of rape is used to describe the

21 Stulman, Jeremiah, 199. Cf. also how the same language used in Isa 3:15 to describe the violation of the daughters of Jerusalem as well as in 2 Sam 13:11, 14 to denote the rape of Tamar: Angela Bauer, Gender in Jeremiah: A Feminist-Literary Reading, StBibLit 5 (New York: Peter Lang Inc., 2003), 114.

22 Susanne Scholz, Sacred Witness: Rape in the Hebrew Bible (Minneapolis, MN: Fortress 2010), 202.

23 Scholz, Sacred Witness, 202.

24 Bauer, Gender in Jeremiah, 114. Bauer furthermore argues that Jeremiah, identified here as female, accuses YHWH of seduction and rape that aligns with the theme Bauer has highlighted elsewhere in the book of Jeremiah with regard to the prophet acting as a "female impersonator lamenting sexual violation by the deity," p. 116.

25 O'Connor, Jeremiah, 87.

26 Cf. the important work by Deryn Guest, "Hiding Behind the Naked Women in Lamentations: A Recriminative Response," BibInt 7/4 (1999): 413-448 as well as Brad E. Kelle, "Wartime Rhetoric: Prophetic Metaphorization of Cities as Female," in Writing and Reading War: Rhetoric, Gender and Ethics in Biblical and Modern Contexts, ed. Brad E. Kelle and Frank R. Ames (Atlanta, GA: Society of Biblical Literature, 2008), 95-112 that both point to the use of sexual violence as a means to capture the destruction of cities during times of war. 
violation of being invaded by the Babylonian Empire. When the people asked why this tragedy had befallen them, the reason given is that it is because of the "the greatness of your iniquity that your skirts are lifted up, and you are violated" (NRSV). The reference to "your skirts lifted up" in the biblical text is euphemistic speech for sexual assault, which together with the Hebrew term חמס ("to suffer violence"), is typically used to describe rape. In this regard, it is important to note that the two verbs used גלה ("uncover") and ("to see") used in this context, also appear in other contexts of sexual violence e.g. Isa 47:31; Ezek 16:36, 37; $23: 29$ and Nah 3:5. ${ }^{27}$

Perhaps even more troubling, in Jer 13:26 in a further continuation of the metaphor of sexual assault, God is depicted as the One who is doing the lifting up of the skirts. ${ }^{28}$ Susanne Scholz emphasises that an active verb is used in this verse with God as the subject, leading to her assertion that in this text, "God is the sexual violator." 29

Scholz furthermore points out that numerous interpreters ignore the portrayal of sexual violence in this text and in particular God's association with it. ${ }^{30}$ Perhaps this is a good example of the way in which trauma hermeneutics is helpful in helping us understand the reasons for this troubling metaphor. Traumatic events such as violence and disaster have been shown to be responsible for the total disintegration of people's religious beliefs and customs when their trust in God, in other people, and in the cosmic order of the world are felt to be unreliable. ${ }^{31}$

Ironically, then, the shocking language that portrays God in terms of a metaphor of sexual assault and even rape is a way in which the prophet offers the people a means to voice something of the terror of their situation; putting into words their most disturbing experiences of being violated. In this regard, O'Connor writes that the most, "outrageous, unbearable, and unspeakable," nature of the image of God raping Zion is exactly the point of the image. ${ }^{32}$ To have been invaded, attacked, occupied, and forcefully removed by the Babylonian Empire,

\footnotetext{
27 Scholz, Sacred Witness, 184.

28 This portrayal of God as Zion's rapist is troubling on so many levels. For one, this divine metaphor seems to sanction the blaming-the-victim argument that is often used in cases of sexual assault. She must have done something to deserve it. But even more so, the association of God with violence that one finds in much of the prophetic witness, including also Jeremiah, becomes even more disturbing when viewed in gendered terms.

29 Scholz, Sacred Witness, 183.

30 Scholz, Sacred Witness, 184. Drawing on the work of Johnny Miles, Scholz warns that "violence unnamed is tacitly violence condoned," p. 184.

31 O'Connor, Jeremiah, 4, 25.

32 O'Connor, Jeremiah, 55.
} 
according to O'Connor "is outrageous, unbearable, and unspeakable." ${ }^{33}$ In terms of a hermeneutics of trauma, one can suggest that the metaphor of rape offers an apt description of what happened during the "speech-destroying disaster" of the Babylonian invasion and destruction that restores the "capacity to speak what cannot be spoken." 34

Similarly, the metaphor of God violently overpowering Jeremiah can be regarded as an example of new language for God that originates in situations of extreme trauma. Those instances in which the "very traditions, beliefs and rituals that stood like a canopy of protection and trust over the community prove useless" ${ }^{\prime 3}$ offer fertile ground for new theological expressions to arise. ${ }^{36}$ Thus in Jer 20 , the outrageous, or even blasphemous, language for God, attests to a prophet who is not content with God and who challenges God in his name by means of language that expresses the violence he experiences in his own body and psyche. ${ }^{37}$ The prophet uses this language to express his experience of being the victim of God's power that has compelled him to proclaim the prophetic word that is likened to a "burning fire shut up in [his] bones" (NRSV Jer 20:7). In Jeremiah's mind, it is the divine word of judgment and destruction that he is obliged to address, and that is ultimately responsible for his current situation of being subjected to violence by the religious establishment as well as his own family and friends. ${ }^{38}$ Furthermore, the violence he is feeling on his own body transpires against the backdrop of the imminent invasion and destruction of the city and temple by the Babylonian empire.

33 O'Connor, Jeremiah, 55.

34 O'Connor, Jeremiah, 55.

35 O'Connor, Jeremiah, 25.

36 Walter Brueggemann argues that Jeremiah's preaching is intended "to shatter old worlds" and "to form and evoke new worlds." For this purpose, one needs "speech [that is not] conventional, reasonable, predictable; it must shock sensitivity, call attention to what is not notices, break the routine, cause people to redescribe things that have long since seemed settled." See Walter Brueggemann, Like Fire in the Bones: Listening for the Prophetic Word in Jeremiah (Minneapolis, MN: Fortress, 2006), 7.

37 As Kathleen O'Connor says it well, "the violence of Jeremiah's world appears in the violence of his God." See O'Connor, "Surviving Disaster," 376.

38 Stulman, Jeremiah, 200. Jeremiah's anger and profound sense of betrayal is thus specifically linked to the fact that when God had called the prophet in Jeremiah 1 to proclaim these words, God had promised to keep him safe. Jeremiah 1:19 states that even when people "fight against you; but they shall not prevail against you, for I am with you, says the LORD, to deliver you." It is no wonder that Jeremiah feels, "deceived," or as Dempsey puts it, "duped" by God. See Carol Dempsey, Jeremiah: Preacher of Grace, Poet of Truth (Collegeville, MN: Liturgical Press, 2007), 105. Cf. also Lundbom, Jeremiah, 54-55. 
Beyond the disturbing nature of the metaphor used for God as violator/rapist, as well as the rejection of Jeremiah's friends, also in light of the problematic gendered connotations God's image presupposes, there is a deep paradox of faith experienced by the prophet while being in prison that quite likely also manifested in the people in exile. Thus, Jeremiah accuses God of overpowering, violating and even raping him, and in the next moment he confesses that God is the source of his salvation; that God had revealed himself in the past as the One who liberates the needy from the evildoers. This paradox of faith whereby one can, in times of severe suffering, proclaim: "I believe" as well as "I do not believe" is most evident in the sharp contrast suggested in Jer 20:13-14. At the same time, Jeremiah sings God's praises only to curse the day of his birth a moment later (Jer 20:14-18). ${ }^{39}$

This demonstration of moving back and forth between praise and lament captures something of the erratic, up-and-down emotions that are typically experienced during situations of extreme duress. Moreover, the conflicting images of God who, in this text and elsewhere in the book of Jeremiah, is portrayed both as destroyer as well as a delivering presence, ${ }^{40}$ reminds us of Jeremiah and the people's struggle to make sense of the inexplicable. In addition, the paradoxical nature of the divine image in Jeremiah 20 offers is a helpful point of entry into investigating the process of contestation and contradiction in terms of God-language that emerges in other communities who have experienced severe trauma. $^{41}$

\section{D "FIND[ING] NEW WORDS TO TALK TO GOD"}

Jeremiah's experience of not being content with God, challenging God in a most abrasive fashion, even using language of sexual violation to describe the violation he had experienced, allows for an understanding of language for God that emerge in contemporary communities under extreme duress. In a fascinating study, Exiled God and Exiled Peoples: Memoria Passionis and the Perception of God During and after Apartheid and Shoah, Andrea Fröchtling investigates

39 Bauer, Gender in Jeremiah, 117. Cf. also a similar paradoxical movement in the book of Lamentations when the speaker the one moment "makes God his bitter assailant and the next his rescuer of countless mercies." See O'Connor, Lamentations, 112.

40 Lundbom argues that "these two confessions ... are intentionally linked" and attest to "a pilgrimage from despair to hope, from doubt to faith." See Lundbom, Jeremiah, 54-55. Cf. also Brueggemann's discussion of the "deliberate juxtaposition"” of Jer 20:713 and 14-18 in Walter Bruegemann, A Commentary on Jeremiah: Exile and Homecoming (Grand Rapids, MI: Eerdmans, 1998), 186.

41 Stulman, Jeremiah, 200. O'Connor describes a similar theological contradiction in terms of the book of Lamentations: "The heart of the book's theological problem is the view that God comes in grace and mercy and the same God also batters, assaults, and punishes." See O'Connor, Lamentations, 113. 
the various images of God that people had during and after the forced removals in Apartheid South Africa as well as in Nazi Germany during the Shoah. She shows how in both instances there was a distinct change in the ways in which people spoke about and to God. She expresses this change in terms of a "rupture" that was profoundly connected to the rupture and upheaval that individuals and communities experienced..$^{42}$ For instance, one elderly South African interviewee said the following about the effect of forced removals on his perception of God during and after being forcefully removed from his land:

We have lost God somewhere on our way from Boomplaats, our home, to the shanty towns all over the place. I don't know - does it sound silly? I mean: How can you lose God on the way? And yet, I say, yes ... we lost him all right. I know from Sunday services that God, he doesn't live only in one place, God, he is everywhere. But then: He is still so much closer to you when you sit under a tree in front of your house.....So this tree....it somehow connected me with God...So when they made everything kapot [destroyed] in these removals, and the house and the tree, all was kapot, then I knew that I had lost the ground on which I used to talk to God. ${ }^{43}$

It is evident in this quote that it the experience of devastating trauma is responsible for new theological constructions of God. One South African woman from Mathopestad describes the difficulty of finding words to express her experience of God: "Words don't just come to you, you must struggle for them. And you will need a new language if you want to make yourself understood. And so, when you suffer, you enter a new land, you enter this bad desert. And then you have to find new words to talk to God, because the old words, they don't work any longer." ${ }^{44}$ Similar to the prophet Ezekiel who felt compelled to rethink the notion of God as being present in the temple in Jerusalem (in Ezek 3:12-13 a mobile God who has "wheels" in order to be present with the exiles in Babylon), one male South African interviewee from Doornkop raises the notion of a "homeless" God that emerged from his own experience of being uprooted. He writes:

When we were forced [sic] removed, they destroyed our church as well, so God, he no longer had a home, God was homeless, and we also, we were homeless. So God, he couldn't stay in Doornkop, he must go with us into exile. And that he did. And when we came back, God, he came back with us. ${ }^{45}$

The language used to describe a God implicated in torture features prominently in the testimonies of many individuals, both during the Holocaust as well

42 Fröchtling, Exiled God, 3-4.

43 Cited in Fröchtling, Exiled God, 118.

44 Cited in Fröchtling, Exiled God, 120.

45 Cited in Fröchtling, Exiled God, 243. 
as Apartheid South Africa. These views align clearly with Jeremiah's feelings of being overpowered, afflicted and violated by God. A male South African interviewee, who during the 1980s had been tortured in a prison in Ladysmith, describes his experience of profoundly feeling the absence of God in a situation where he was being tortured: "I cried, I cried to God for help, but God didn't hear me. ...I couldn't think any longer, just scream to God who was gone and who had left me alone in this hell." ${ }^{46}$

A member of the security police actually told him: "See your God hasn't helped you, because we are God here. It is us to determine who is to live and who is to die. And you, you are going to die now." It is at that moment when $\mathrm{Mr}$ Dlamini, as he is called, realised that his torturers, "really were like God, a bad God," for the reason that "they were almighty." His experience was that he was completely and utterly in their power. ${ }^{47}$

Mr Dlamini's testimony is interesting in the sense that it acknowledges a distinction between God and the perpetrators who act as God. In the story told by Elie Wiesel about a twelve year-old girl who was repeatedly sexually violated by Nazi soldiers, God is more directly implicated: "Suddenly she turned her darkened eyes toward me. God was still in them. The God of chaos and impotence. The God who tortures twelve-year-old children." 48

However, one also finds amongst the individuals whom Fröchtling interviewed God images that move beyond an understanding of God's hostile presence or impotent absence, to rather reflect something of God's comforting, salvific presence that counters notions of an abusive God. A female resident of Imbali, South Africa, explains that God was not able to respond to her uncontrollable weeping, because He was also crying. She says: "I want to say that God if he was a loving God, then he must have stopped speaking because he was crying with the people, crying with his people. And you can't cry and talk at the same time, you can't." 49

Ms Mandelbaum, a Holocaust survivor, goes even further to imagine God's silence in terms of a mother who is weeping inconsolably for losing her

46 Cited in Fröchtling, Exiled God, 133.

47 Fröchtling, Exiled God, 133.

48 Elie Wiesel, The Accident (New York: Hill \& Wang, 1997), 92. Cited in Fröchtling, Exiled God, 134. As Fröchtling rightly points out in her reflection on these testimonies, it is the experience of torture that profoundly challenges the traditional understanding of God as omnipotent, omniscient and all-loving - it is because "the overall coherence of life is shattered to such an extent" in a situation of torture that God images of "an absent, an abusive or a silent God" emerge (p. 134).

49 Cited in Fröchtling, Exiled God, 195. 
child, drawing upon an incarnational theology where God becomes that wailing woman:

I looked at the mother again, and all of a sudden I was sure that God, he was there, no, not there, here. God was in the wailing, mourning mother, in fact, God was that suffering mother. And then I understood God's silence - because what can a mother say who has just lost her beloved child? What can a mother say, or a father, for that matter, who has lost more than six million of his children. ${ }^{50}$

In view of these diverse and contradictory ways of speaking about God in situations of tremendous anguish and distress, one finds that the act of facing the tormenting God is rooted in some other understanding of God that is not content with God, and thus seeks to hold God accountable. It is this act of contestation that is important for a questioning faith that holds on to God while also raising one's fist at God. I discuss this idea in the next section.

\section{E ANI MAAMIN?}

How does one go about making sense of such deeply divergent, and in many instances also disconcerting metaphors for God that emerge in situations of duress as evident above? And, perhaps even more confounding for some, is the realisation that many believers who name God as abusive, as the torturer God and in the case of Jeremiah, even the rapist God, still can cling onto and pray to this God?

Something of this sentiment is evident in the song "Ani Maamin," ("I believe") that was regularly sung during the Holocaust as thousands of Jews were led to Auschwitz, Treblinka, Majdanek. ${ }^{51}$ The faith reflected in this song is very much a faith that occurs in spite of and even against God as evident in Elie Wiesel's poem "Ani Maamin" in which the refrain "I believe" appears throughout the long poem in which the patriarchs Abraham, Isaac and Jacob all rise up to challenge God about the atrocities they have seen in the Holocaust. This is powerfully illustrated in the following doxology to a paradoxical God cited in Wiesel's poem:

Ani maamin, ani maamin.

God possible -

And impossible.

God present? How can you?

God absent? How can you?

50 Cited in Fröchtling, Exiled God, 197. Cf. also the exposition on the Mourner God in my book, L. Juliana Claassens, Mourner, Mother, Midwife: Reimagining God's Liberating Presence (Louisville, KY: Westminster John Knox, 2012), 18-40.

51 Yitzchak Dorfman, "Ani Ma'amin," Chabad.org, online: http://www.chabad.org /library/article_cdo/aid/332502/jewish/Ani-Maamin.htm. 
How can man

Commit such evil

Without you?

Or with you?

Ani Maamin?

How is one to believe?

How is one not to believe ${ }^{52}$

This paradox evident in this doxology is well-illustrated in the words of Malkiel, one of Wiesel's characters in the novel, The Forgotten:

One man said to me, "In a camp in Poland I saw the extreme of human cruelty. I saw a German officer slaughter a father in front of his four children. That day I lost my faith." "I can understand him," Malkiel said. "Another man told me, "In a camp in Poland I saw the extreme of human solidarity. I saw three strangers who sacrificed their sleep and their health to save a sick prisoner. That day my faith was restored." "I can understand him too," Malkiel said. ${ }^{53}$

The faith underlying these believers' experience of extreme suffering that is also reflected in the contradictory images used by the prophet Jeremiah is a faith that challenges God - a faith that as was shown in this article as not being content with God. This ongoing engagement with God amidst difficult circumstances is essential for the survival of God. Drawing on the work of Johann Baptist Metz, Fröchtling rightly notes that "prayer after Auschwitz is [only] possible because there had been prayer in Auschwitz." 54

However, this claim needs to be interrogated because it has profound implications for our own and others' understanding of God. A good illustration of how the language one uses for God in situations of profound suffering is not just theoretical or inconsequential in nature emerged from a recent class I taught on the book Lamentations that focused on believers' struggles to make sense of God in the midst of the extreme violation they experienced by the hand of the Babylonian invaders. After playing "Ani Maamin," set to footage that memorialised some of the children who died during the Holocaust, one student who has been involved with the \#OpenStellenbosch and \#FeesMustFall movements became quite upset. He drew connections to his own experience of suffering, pain and humiliation during Apartheid and colonisation that he felt continued to cause great economic hardship for many Black and Coloured individuals and communities in South Africa. The idea that one can still profess, "I believe," to a God who, in his experience, had caused great suffering in his and others' lives

52 Elie Wiesel, Ani Maamim: A Song Lost and Found Again (New York: Random, 1973), 25. Cited in Fröchtling, Exiled God, 270.

53 Elie Wiesel, The Forgotten (New York: Shocken Books, 1995). Cited in Fröchtling, Exiled God, 144.

54 Fröchtling, Exiled God, 150. 
evoked a strong reaction in him as he maintained that this God should be rejected as the Apartheid God who came on a ship together with Jan van Riebeeck. For him, this God is still responsible for the glaring inequality that he feels on his own body and psyche. Even just talking about this experience was very painful to him, as evident in his exclamation that the classroom setting had become a violent space for him, and that white people should not be allowed to talk about God. ${ }^{55}$

While writing this article, this exchange caused me to reflect about what precipitated this student's response, and even more importantly, how this response challenges my own theological reflection as well as pedagogical practices. ${ }^{56}$ One thing was clear, namely that God-language that emerges from situations of suffering continues to be a deeply existential and theological issue for students, and I would suspect also for other believers. This underscores the importance of continuing to reflect on our constructions and reconstructions of God in contexts of trauma. I mention four points that reflect my thinking thus far:

Firstly, one must admit that violent metaphors for God are profoundly problematic in nature and ought to be challenged. For instance, the depiction in Jeremiah 20 of God's overpowering, abusive presence aligns with the God-language used by many of the interviewees in Fröchtling's study. One Auschwitz

55 This experience has led me to reflect on the notion of what a "safe space" in terms of a pedagogical setting means. As teacher, I am deeply committed to a feminist ethos of (1) honouring all voices, (2) interrogating power relations and (3) reconstituting community. Cf. Carolyn J. Sharp, “'Are You For Us, or For Our Adversaries?' A Feminist and Postcolonial Interrogation of Joshua 2-12 for the Contemporary Church," Int 66/2 (2012): 141-152. However, my student's angry outburst caused some of the other students to withdraw, conceivably experiencing the classroom as a violent space as well. For me as teacher, the challenge therefore remains to truly create a space where all voices are honoured, all the while acknowledging the reality of power and privilege.

56 I have been helped in this regard by the work of Felman who reflects on the crisis in her classroom when presenting her class with some testimonies by Holocaust Survivors in the documentary, Shoah. In her article, Shoshana Felman, "Education and Crisis," in Trauma: Explorations in Memory, ed. Cathy Caruth (Baltimore, MD: John Hopkins University Press, 1995), Felman describes how many of her students found themselves greatly disturbed, at a loss for language, disorientated - in essence how the class was falling apart. She captures her students' experience of crisis in the following way: "they sought out each other and yet felt they could not reach each other," (p. 50). Felman further explains how she in the next class meeting helped to reframe the experience for the students by asking them to write an essay reflecting on the experience in class that had the purpose of helping students draw connections from this experience. Felman concludes that "teaching in itself, teaching as such, takes place precisely through crisis" (p. 55). 
survivor describes this dilemma well: "How can you live with an abusive God when your ultimate refuge is also trapped in a cycle of violence?"57

In this regard, O'Connor's critique of divine images associated with images of torture and abuse is important. She argues that if one were to leave violent God imagery unchecked, acts of violence and abuse in our midst may also be tolerated. ${ }^{58}$ Moreover, feminist scholars remind us that language of rape and sexual assault may actually contribute to the ongoing degradation of women in particular, especially as it pertains to the naturalisation of violence as a means of "bringing women under control". 59

Secondly, the paradoxical imagery for God that appears in many of these believers' images for God is helpful in that it serves the purpose of challenging or mitigating violent imagery for God. ${ }^{60} \mathrm{I}$ saw something of this in my own reaction to my student's comments on the "Apartheid God" when I responded by saying that there also is another God who fought against apartheid and who was part of the ongoing quest for justice, as evident in the life and work of some of the anti-apartheid leaders such as Desmond Tutu, Alan Boesak and Beyers Naudé. I tried to argue that there are deep religious traditions that sought to challenge the proponents of an Apartheid theology and that sadly used the Bible to justify apartheid. In my mind, it is this God who continues to stand by those who are suffering the indignity of the slow violence of poverty that continues to stifle hope and life and joy amongst its victims. A South African interviewee, Ms Dlamini, shares a similar sentiment: “... [w] hen I grew older I saw that the God of the old missionary was not my God. My God hated Apartheid and injustice, my God wanted me to stand up against Pharaoh..."61

57 Cited in Fröchtling, Exiled God, 230. Fröchtling formulates this dilemma as follows: "A violent God cannot be called against a violent God. If the very nature of God is perceived as violence and abuse then God can no longer be the haven refuge against that very violence," 230.

58 O'Connor, Lamentations, 110.

59 Mary E. Shields, "Impasse or Opportunity or ...? Women Reading Jeremiah Reading Women," in Jeremiah (Dis)Placed: New Directions in Writing/Reading Jeremiah, ed. A. R. Pete Diamond and Louis Stulman (London: Bloomsbury T\&T Clark, 2011), 302.

60 According to O'Connor, the image of God's tears in Jer 8:22-9:1 ruptures God language and dethrones the disturbing divine imagery of God as an angry husband and the architect of war. See Kathleen O'Connor, "The Tears of God and Divine Character in Jeremiah 2-9," in God in the Fray: A Tribute to Walter Brueggemann, ed. Tod Linafelt and Timothy K. Beal (Minneapolis, MN: Fortress, 1998), 172-185. And in reference to Lam 3:33, O'Connor proposes that images that speak of a "God who does not afflict or grieve willingly," the poet in Lamentations "chips away at images of an abusing God, if only for an instant." See O’Connor, Lamentations, 115.

61 Cited in Fröchtling, Exiled God, 100. 
Using alternative theological constructions in order to counter violent formulations for God is a good example of Caputo's notion of using the "weakness of God" - those central beliefs of faith, hope, love and justice" as the basis for the act of contestation. ${ }^{62}$ In my response to my student, I was intuitively drawn to a theology that is not content with God, challenging harmful constructions of God as also was evident in Herman Van Veen's song with which this article started. My hope is that this act of contradiction and contestation in class may also help students to understand the importance of continuing to challenge harmful, limiting God-language, which as evident in my student's reaction, continues to do much harm to people today.

Thirdly, I realised in this class how important it is to break the direct link between the perpetrator's actions and God. When Jeremiah claims in Jer 20 that God had violated him, the abuse comes not only from the violent rule of the Babylonian Empire in which he lived and worked; it was also closer to home from his experience of being violated and tortured by religious leaders and his own family and friends. In the examples cited above, the Nazi torturers, the Apartheid security police, as well as the scores of silent accomplices who are responsible for inflicting pain and torment. It is significant that at least half of Fröchtling's interviewees intuitively made this distinction, and subsequently began to explore alternative formulations for God. They focused more on images of a suffering God, ${ }^{63}$ a God who is present in acts of comfort and care by fellow human beings - as is evident from the example of Malkiel cited above, and further explicated by Melissa Raphael in her important monograph, The Female Face of God at Auschwitz. ${ }^{64}$

Fourthly, the challenge to God finds its roots in the rich resources offered by the wealth of our religious traditions. It is interesting in Van Veen's song that, in the second stanza, he lists a range of religious activities: kneeling and buying a rug, veiling oneself, practising circumcision, honouring food and drink laws, eating chicken soup, folding one's hands and dedicating and entrusting one's

62 Caputo, The Folly of God, 35. Cf. also Fröchtling who argues that "in many cases, the notion of an abusive God comes along with countering that very God, and even amongst those who indicated that they would stick to an abusive God, chutzpah and Jobian God-talk are common occurrences, with para-doxically, God being called against God." See Caputo, Exiled God, 235.

63 Fröchtling, Exiled God, 233. It is interesting to note Fröchtling's observation that it predominantly were women who continued to be drawn to abusive imagery for God while more men either walked away from religion or started using imagery pertaining to a suffering God (p. 234).

64 In her fascinating study, Melissa Raphael, The Female Face of God at Auschwitz: A Jewish Feminist Theology of the Holocaust (London: Routledge, 2003), Raphael elaborates on the manifold ways in which God was thought to present in the ordinary acts of women caring for one another in the death camps. 
whole life and death to him or her or it. These acts of devotion form the basis of his challenge to God. Moreover, these religious activities are intertwined with the questioning faith that permeates the entire song as evident in the final question, "Sir?"65

The role of religious traditions as the source of the believers' questioning of God is also evident in Jeremiah's invocation of the image of the Liberator God (Jer 20:13) who decisively acts to save those who are in bondage. The Liberator God, an image that speaks of justice and equity and healing for those who are suffering throughout the biblical witness (e.g. Deut 10:18; 24:17-18; Ps 72:1213 ) is an example of the way in which there are resources deep within our religious traditions that may be used to challenge the notion of an abusive God. But perhaps even more importantly, we can also use these to challenge the ongoing abuse by fellow human beings. ${ }^{66}$

\section{F CONCLUSION}

I realised after my experience in class that the uncomfortable tension between "I believe" and "I do not believe" is not easily resolved. The reason for this is that in many instances, as represented in Herman Van Veen's song as well as in my student's reaction in class, injustice and violation continue. One of Elie Wiesel's characters in his The Trial of God reminds us of our obligation to continue to keep on challenging God:

But the killers kill in His name. Not all? True, but numbers are unimportant. Let one killer kill for His glory, and He is guilty. Every man

65 The original Dutch lyrics read as follow:

"En ik zal knielen en een kleedje kopen

Voortaan gesluierd gaan

En me besnijden

Varkenshaasjes laten liggen

Bier en wijn vergeten

Kippensoepjes eten

Mijn handen vouwen

En mijn hele dood en leven, aan hem of haar of het

Toevertrouwen

Meneer?"

66 Cf. Miller's exposition of the sabbatical principle in the Deuteronomic code in which the call to do justice to the most vulnerable members of the community is connected to the memory of being delivered by God from slavery in Egypt: Patrick D. Miller, The Ten Commandments, Int (Louisville, KY: Westminster John Knox, 2009), 137-143. 
who suffers or causes suffering, every woman who is raped, every child who is tormented implicates Him. ${ }^{67}$

One could add to this list of individuals and groups who implicate God, "good Christian people" who continue to make their LGBTIQ brothers and sisters feel unwelcome in church. Similarly, one can add "moral people" who act immorally by not challenging systems that reinforce glaring social inequalities.

The examples of biblical characters such as Jeremiah's act of challenging God, in the name of God echo similar sentiments felt by courageous voices of believers from different parts of the world. These believers share the experience of finding themselves in undignified circumstances. They pray to God in spite of God; against God; in the name of God. This is perhaps an important skill to cultivate. ${ }^{68}$ This type of faith that not afraid to question God; is comfortable with paradox - and is essential for believers who are committed to challenging injustice perpetuated in God's name. Moreover, this act of liberating God from the weight of all the damage and hurt conducted in his name might be salvific for us as in our pursuit to heal ourselves and our communities.

\section{BIBLIOGRAPHY}

Bauer, Angela. Gender in the Book of Jeremiah: A Feminist-Literary Reading. StBibLit 5. New York: Peter Lang Inc, 2003.

Boase, Elizabeth and Christopher G. Frechette, eds. Bible through the Lens of Trauma. SemeiaSt 86. Atlanta, GA: Society of Biblical Literature Press, 2016.

Becker, Eve-Marie, Jan Dochhorn, and Else Holt, eds. Trauma and Traumatization in Individual and Collective Dimensions: Insights from Biblical Studies and Beyond. Göttingen: Vandenhoeck \& Ruprecht, 2014.

Brueggemann, Walter. Like Fire in the Bones: Listening for the Prophetic Word in Jeremiah. Minneapolis, MN: Fortress, 2006.

. A Commentary on Jeremiah: Exile and Homecoming. Grand Rapids, MI: Eerdmans Publishing Company, 1998.

Caputo, John D. The Folly of God: A Theology of the Unconditional. Eugene, OR: Polebridge Press, 2016.

Claassens, L. Juliana. Mourner, Mother, Midwife: Reimagining God's Liberating Presence. Louisville, KY: Westminster John Knox, 2012.

Dempsey, Carol J. Jeremiah: Preacher of Grace, Poet of Truth. Collegeville, MN: Liturgical Press, 2007.

Dorfman, Yitzchak. "Ani Ma'amin." Chabad.org. Online: http://www.chabad.org /library/article_cdo/aid/332502/jewish/Ani-Maamin.htm.

67 Elie Wiesel, The Trial of God (New York: Schocken Books, 1995), 54.Cited in Fröchtling, Exiled God, 140.

68 Fröchtling, Exiled God, 279. Cf. Wiesel's poem Ani maamim that concludes with what Wiesel describes as a "final declaration of hope and faith against hope and faith, against God, in spite of God." 
Felman, Shoshana. "Education and Crisis." Pages 13-60 in Trauma: Explorations in Memory. Edited by Cathy Caruth. Baltimore, MD: John Hopkins University Press, 1995.

Fröchtling, Andrea. Exiled God and Exiled Peoples: Memoria Passionis and the Perception of God during and after Apartheid and Shoah. ÖSt 22. Berlin: LIT Verlag, 2002.

Garber, David G. "Trauma and Biblical Studies." CurBR 14/1(2015): 24-44.

Guest, Deryn. "Hiding Behind the Naked Women in Lamentations: A Recriminative Response." BibInt 7/4 (1999): 413-448.

Kelle, Brad E. "Wartime Rhetoric: Prophetic Metaphorization of Cities as Female." Pages 95-111 in Writing and Reading War: Rhetoric, Gender and Ethics in Biblical and Modern Contexts. Edited by Brad E. Kelle and Frank Ritchel Ames. Atlanta, GA: Society of Biblical Literature, 2008.

Lundbom, Jack R. Jeremiah among the Prophets. Eugene, OR: Cascade Books, 2012. Miller, Patrick D. The Ten Commandments. Int. Louisville, KY: Westminster John Knox Press, 2009.

O'Connor, Kathleen M. "How Trauma Studies Can Contribute to Old Testament Studies." Pages 210-222 in Trauma and Traumatization in Individual and Collective Dimensions: Insights from Biblical Studies and Beyond. Edited by Eve-Marie Becker, Jan Dochhorn, and Else Holt. Göttingen: Vandenhoeck \& Ruprecht, 2014. . Jeremiah: Pain and Promise. Minneapolis, MN: Fortress Press, 2011. "A Family Comes Undone." RevExp 105/2 (2008): 201-212. "Surviving Disaster in the Book of Jeremiah." WW 22/4 (2002): 369-377. . Lamentations and Tears of the World. Maryknoll, NY: Orbis Books, 2002. "The Tears of God and Divine Character in Jeremiah 2-9." Pages 172-185 in God in the Fray: A Tribute to Walter Brueggemann. Edited by Tod Linafelt and Timothy K. Beal. Minneapolis, MN: Fortress, 1998.

Raphael, Melissa. The Female Face of God in Auschwitz: A Jewish Feminist Theology of the Holocaust. London: Routledge, 2003.

Scholz, Susanne. Sacred Witness: Rape in the Hebrew Bible. Minneapolis, MN: Fortress, 2010.

Seibert, Eric A. The Violence of Scripture: Overcoming the Old Testament's Troubling Legacy. Minneapolis, MN: Fortress, 2012.

Sharp, Carolyn J. “"Are You For Us, or For Our Adversaries?': A Feminist and Postcolonial Interrogation of Joshua 2-12 for the Contemporary Church." Int 66/2 (2012): 141-152.

Shields, Mary E. "Impasse or Opportunity or ...? Women Reading Jeremiah Reading Women." Pages 290-302 in Jeremiah (Dis)Placed: New Directions in Writing/Reading Jeremiah. Edited by A. R. Pete Diamond and Louis Stulman. London: Bloomsbury T. \& T. Clark, 2011.

Steyn, Pieter. "NG Kerk besluit wéér teen gays." Netwerk24 (10 November 2016). Online: http://www.netwerk24.com/Nuus/Algemeen/ng-kerk-besluit-weer-teengays-20161110.

Stulman, Louis. "Reading the Bible through the Lens of Trauma and Art." Pages 177192 in Trauma and Traumatization in Individual and Collective Dimensions: Insights from Biblical Studies and Beyond. Edited by Eve-Marie Becker, Jan Dochhorn, and Else Holt. Göttingen: Vandenhoeck \& Ruprecht, 2014. 
Claassens, "Not Being Content with God," OTE 30/3 (2017): 609-629

. Jeremiah. AOTC. Nashville, TN: Abingdon, 2011.

Stulman, Louis and Hyun Chul Paul Kim. You are My People: An Introduction. Nashville, TN: Abingdon, 2010.

Wiesel, Elie. The Accident. New York: Hill \& Wang, 1997. . The Forgotten. New York: Shocken Books, 1995. . The Trial of God. New York: Schocken Books, 1995. . Ani Maamim: A Song Lost and Found Again. New York: Random, 1973.

L. Juliana Claassens, Professor of Old Testament, Department Chair of Old and New Testament, Head of Gender Unit, Faculty of Theology, Stellenbosch University, Stellenbosch, South Africa. Email: jclaassens@sun.ac.za. 